\title{
熊鈴製作を通した物づくり教育 一有明高専専攻科基礎設計特別演習での実践報告一 \\ Engineering Education through Manufacturing Bear Bells \\ A Report on Practical Activities of Advanced Exercise for Design Fundamentals in Advance Engineering Course of Our College
}

○正 川崎義則（有明高専） 正 木下正作（有明高専）

Yoshinori KAWASAKI, Ariake Nat. Col. of Tech., 150 Higashihagio-machi, Ohmuta, Fukuoka Shosaku KINOSHITA, Ariake Nat. Col. of Tech.

In our laboratory, problem based learning type studies have been carried out as graduation research programs for several years. They are developments of equipments for environment and welfare.

This report is concerned with the practical activities about manufacturing bear bells as one of these problem based learning programs. This program was carried out by the advanced engineering course students in the advance exercise for design fundamentals. Through manufacturing bear bells, our students understood that manufacturing design, considering of working process, and use of effective working jigs took very important role in manufacturing. In engineering (manufacturing) education at colleges, necessity of some practical design exercise related to manufacturing design and designing working jigs etc. are emphasized here.

Key Words: Manufacturing Education, Engineering Education,

1.はじめに

一昨年の夏，ヒューマンネットワーク高専(HNK) ${ }^{1)}$ の仲

間とキャンプ・登山をした際, 新潟の友人が腰につけた妙 高熊鈴，その形と音色の美しさに魅了されたのが，ことの 始まりである。

㷌校後, 専攻科生に「作ってみないか?」との私共の呼 びかけに強い興味を示し「はい」と即答した学生に、「た だし鋳造以外の方法で」と製作方法に制限を課した。これ は，本校に鋳造設備がないことの他に，物作りには適当な 制限を設けることが創意工夫の発揚の引き金になるとの考 えからである。 ${ }^{2)}$

本報告は，このような経緯で，専攻科の基礎設計特別演習 の一課題として行った熊鈴製作を通した物づくり工学教育 の実践報告である。この実践を通して，学生は，正しい物 づくりを進めるためには治具・取り付け具の工夫が必要不 可欠であること，そして製作のことを考えた生産設計の重 要性を学ぶことができたであろう。

\section{2. 基礎設計特別演習}

専攻科 1 年生カリキュラム, 後期 2 単位, 15 回. 前半 で，生産設計全般のゼミ(4回), 穴あけ治具の設計演習 (2回)を経て, 後半熊鈴の製作 (9 回)を行った.

2.1 生産設計ゼミ

工業製品の開発においては, 製品設計と生産設計に大別 できる. 高専・大学の設計教育においては, 具体的な例で 設計演習を行うとはいうものの，すべて前者，製品設計を 学ぶことになる。したがって，製作が容易で，品質の安定 を保証した，安価な物づくりを意味する生産設計は，企業 に入ってからということになる. しかしながら，物づくり を学ぶには，この生産設計を抜きにしては意味がないと考 え、今回, 本校専攻科の授業に, 生産設計を導入した。

まず，第一ステップとして，生産設計の基礎事項 ${ }^{3)}$ を習 得することが賢明であるとの考えから，ゼミ形式で学ぶこ とにした，生産設計の要点を, 鋳造, 鍛造, 塑性加工, 溶 接, 機械加工, 熱処理, および組み立てについて学んだ.

\section{2 治具設計演習}

物づくりを支えるもうひとつの技術がある．それは，治 具・工具・取り付け具であり, 残念ながら, これも学校で はほとんど学ぶことはないのが現状である.

そこで，簡単な機械部品 (鋳物部品を選定)を例に，加工 工程を考えさせ, 各加工工程で, 工作物の取り付け取り外 しが簡単で，かつ確実に製作できる治具の設計を課した。 Fig. 1，Fig. 2 に，鋳物製素材および完成品の図面をそれ ぞれ示す．旋盤治具と穴あけ治具が必要となった。この演 習を通して, 学生は, 部品加工を行う際, 自然と加工手順 (工程)を考えることができるようになったと思われる。こ れが，物づくりの第二ステップである.Fig. 4 〜 Fig. 6 に, 加工工程, および加工治具の例を示す.

ただしここでは：加工工程および治具の設計のみで, 実際の機械加工の実践までは行わなかった．実加工演習は 来年度以降の課題であり，またここで得られた治具に関 する成果は, 次年度の効果的なテキストとして利用でき る.

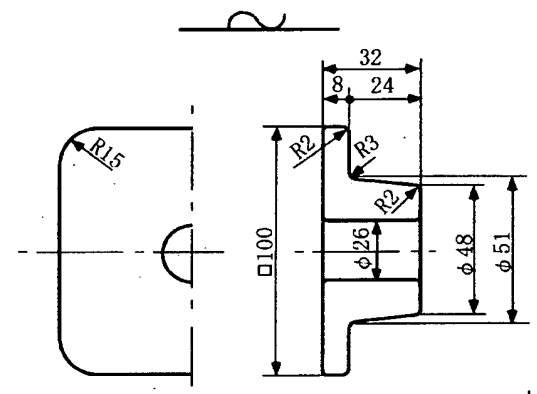

注）・本図は、鋳物素材図である。 ・指示なきカド部はR1と学る。

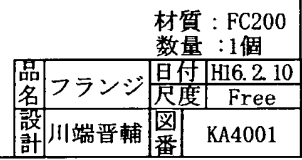

Fig. 1 Cast material 


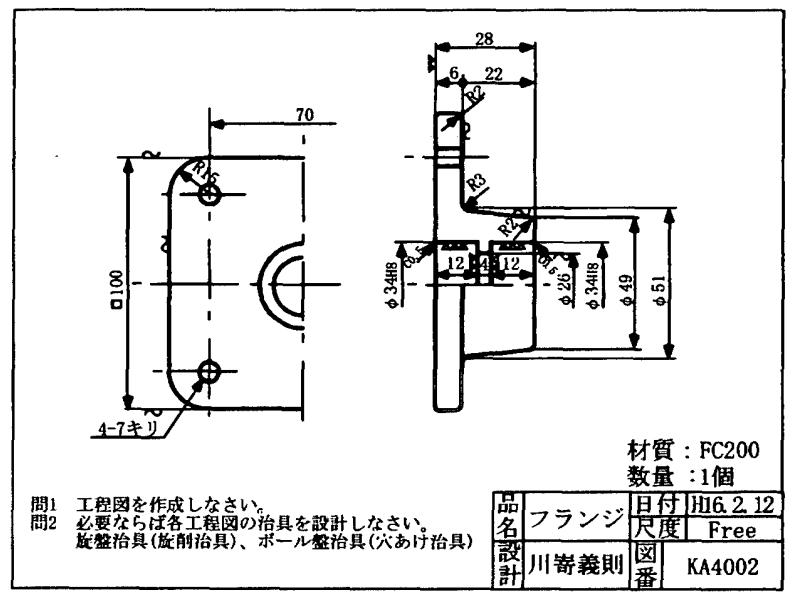

Fig.2 Manufacture drawing

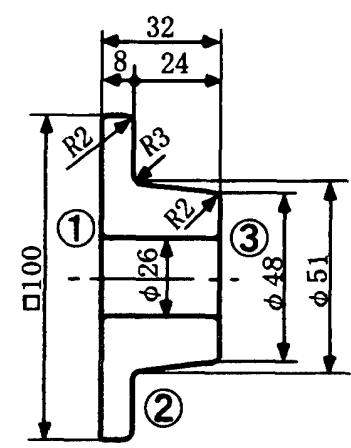

Fig.3 Cast material

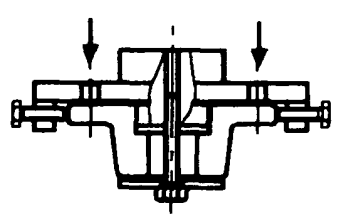

第二工程

・穴あけ治具を用いて，(2)部 の 7 キリ 4 ケ所を加工する.

Fig.5 The 2nd process

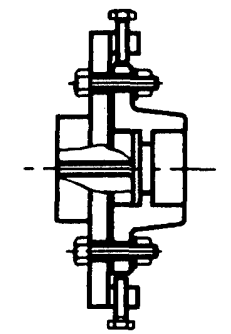

\section{第三工程}

・穴あけした 7 キリ穴を利用して, M6ボルト・ナットで治具を固定. (第二工程の穴あけ治具を兼用して 旋削治具として使用する.)

・ (3)側端面を $2[\mathrm{~mm}]$ 旋削する.

・ (3)側の内径を $\phi 34[\mathrm{~mm}]$ に旋削する.

Fig.6 The 3rd process

3. 掂跲のこと

以上，第一，第二ステップの準備を行ったうえで，学生 をメインテーマである熊鈴つくりへ導入した。
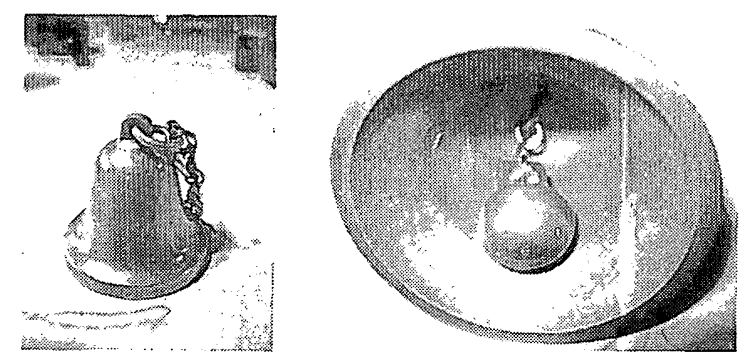

Fig.7 Original bear bell
Fig. 7 に示すような黄銅製の熊鈴が対象である．妙高原 のお土産店で販売されているこの熊鈴は，真鍮鋳物製で重 さ約 $150[\mathrm{~g}]$ である. 妙高高原町に在住の友人から 1 個提 供いただいた物を学生に与えた。専攻科生 5 名を 2 名 (A 班)と 3 名 (B班)に班分けした。

課題は，つぎの通りである。「鋳造以外の加工法でこれ と同じ形状で, 音色もできるだけ近いものを製作しなさ

い. 材質は黄銅とする．工作機械は，本校に既設のものに 限る.ただし，必ず，完成させること」.

塑性加工も，加工法の一つとして導入して欲しいという 我々の狙いもあったが, 結果的には, A, B両班とも, 旋 盤加工を採用することになった。ただし，学生も班として の自己主張が強く，A 班はNC 旋盤での自動加工，B班は 沉用旋盤での総形バイトによる手作業による加工と，それ ぞれ異なった加工法での製作となったことは，興味深い結 果となった.

以下に,それぞれの班での製作内容を, 彼らのレポート に従って示していきたい.

\subsection{A理 (NC旋盤による製作)}

1）製作図：A 班は，オリジナル熊鈴を忠実に再製作する 考えに基づいている. 従って, Fig. 8 は熊鈴のスケッ チ図であり，製作図でもある：

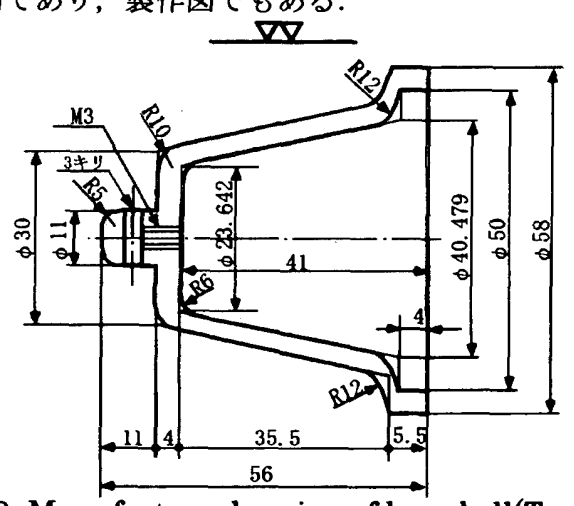

Fig.8 Manufacture drawing of bear bell(Team A) (The original bear bell)

2）使用工作機械，工具など

- 使用工作機械

- 滝沢実習教育用 CNC 旋盤 : MODEL TSL360CNC

・日立精機 NCフライス盤 : NCMV-72

・日立工機ロターリーバンドソー : CB22FA

・吉田卓上ボール盤 : YBD-360

- 使用刃具

・内径切削用ボーリングバー : (京セラ) SCLPR1210B-08

・ボーリングバー用チップ : (京セラ)CPMH090308

・外径用右片刃バイトホルダー：

・外径用右片刃バイトホルダー(東芝タンガロ1) DNMG150404-22

・ツイストドリル : $20[\mathrm{~mm}], 10.5[\mathrm{~mm}], 5.2[\mathrm{~mm}], 2.3[\mathrm{~mm}]$

・M3 ハンドタップ

- 測定具

・150[mm]標準ノギス ・150[mm]デプス

3）加工工程と考案した治具など

(1)熊鈴本体加工

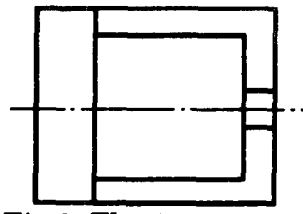

Fig.9 The 1st process - 外径捨て削り

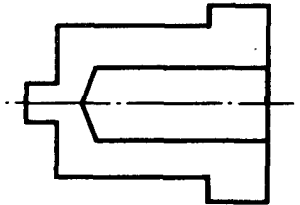

Fig.10 The 2nd process - 20 キリ穴加工 


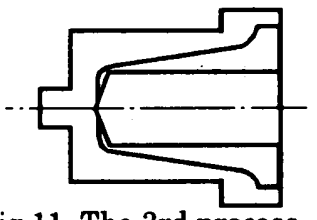

Fig.11 The 3rd process ・内径仕上げ削り

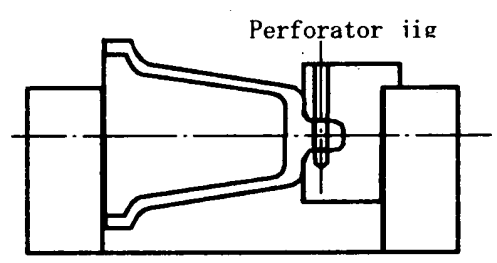

Fig. 13 The 5 th process ・5 キリ下げ穴加工

(2)鈴玉加工

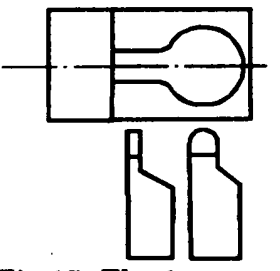

Fig.15 The 1st process - 鈴玉外径加工

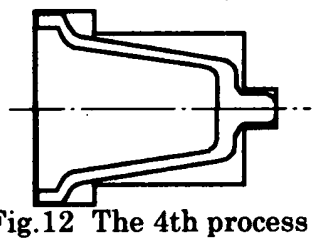

- 外径仕上削り

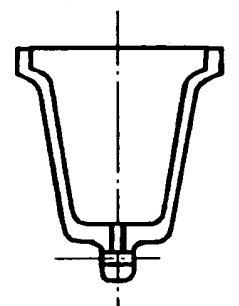

Fig.14 The 6th process ・玉取り付け金具用 M3 ねじ加工

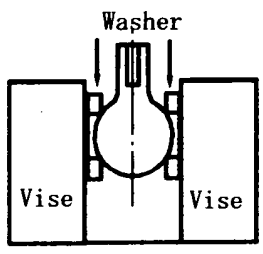

Fig.16 The 2nd process - $3[\mathrm{~mm}]$ 溝入れ加工

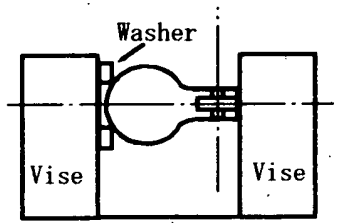

Fig.17 The 3rd process

・M3 ねじ下穴加工及びM3 ねじ加工

(3)鈴玉取り付け金具

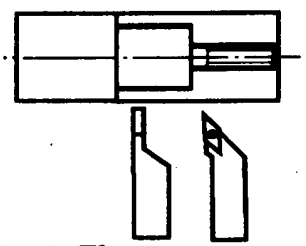

Fig.18 The 1st process ・外径及びM3 ねじ加工

Fig.20 The 3rd process -2.5 キリ及びM2 下穴加工

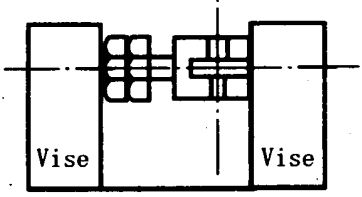

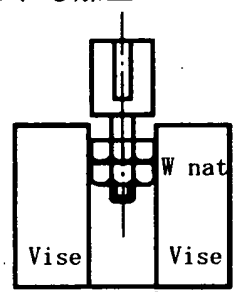

Fig.19 The 2nd process $\cdot 3[\mathrm{~mm}]$ 溝加工

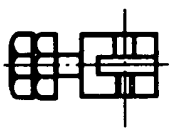

Fig.21 The 4th process ・M2 ねじ加工
4）完成品した A 班の熊鈴をFig. 22 に示す.

5）感想：前川良平君のレポートより

ここで学んだことは，ある物を作るときにいろいろな方 法があることが分かったこと. 今回作った熊鈴は, 鋳造に よる方法が一般的だが，別の方法でも加工はできる. 我々 は切削加工で熊鈴を製作したが，この加エでは，時間・コ ストがかかりよい方法でないかもしれないが，オリジナル と同じ形状に切削加エで作れることは分かった．同時に，
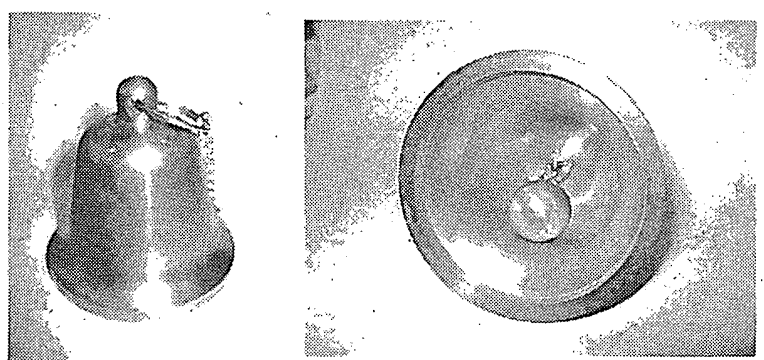

Fig. 22 Bear be11 manufactured by Team A 熊鈴を作るうえで，加工手順を考えること， その加工を行 うために治具を考案しなければならないことを知った。こ れまでは，完成図面を実習工場に出し，加工してもらって 完成品を見るのみであったので，加工手順などを考えるこ となどなかった. 今回, この授業で, いい経験ができた.

また, 私はNCプログラム作成を担当したが, 各工程で の切削条件などを考え, 試行錯誤で大変だったが, きれい に仕上げたときは本当にいい経験ができたと思った.

今回, 音色についての分析・評価は時間内ではできなかっ たし，実際のものづくりでの問題設定は簡単ではないと思 うが, 今回の経験を今後に十分生かせると考えている.

\subsection{B理 (沉用旋盤による製作)}

1）製作図：B 班は，熊鈴のどのような音が有効であるか 調査して，複雑でより大きい音が出るような形状を設 計した. Fig. 23 に製作図を示す.

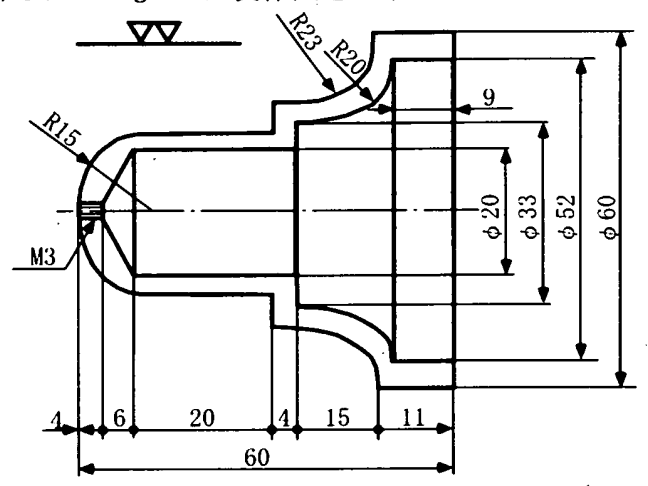

Fig. 23 Manufacture drawing of bear bell (Team B)

2）使用工作機械，工具など

・使用工作機械

- 桐生機械高速強力旋盤 : MODEL LM-229

・日立精機 NC フライス盤 : NCMV-72

・日立工機ロターリーバンドソー : CB22FA

・吉田卓上ボール盤 : YBD-360

- 使用刃具

・総形バイト : 3 種類・・グリバイト : 2 種類

・突っ切りバイト : 3 種類 ・右片刃バイト: 1 本.

・内径加工用バイト : 1 本 ・M3 タップ

・ツイストドリル : $50[\mathrm{~mm}], 34[\mathrm{~mm}], 20[\mathrm{~mm}], 2.5[\mathrm{~mm}]$

- 測定具

$\cdot 150[\mathrm{~mm}]$ 標準ノギス ・150[mm]デプス

3）加工工程と考案した治具など

(1)熊鈴本体加工

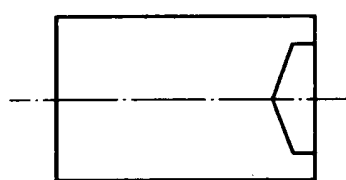

Fig.24 The 1st process ・ 50 キリ穴あけ加工

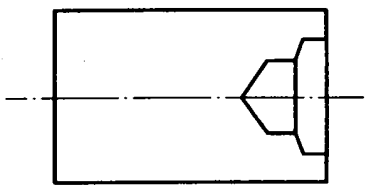

Fig.25 The 2nd process ・ 34 キリ穴あけ加工 


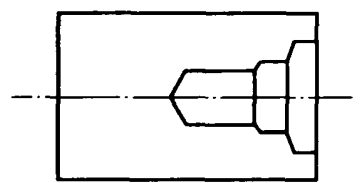

Fig.26 The 3rd process - 20 キリ穴あけ加工

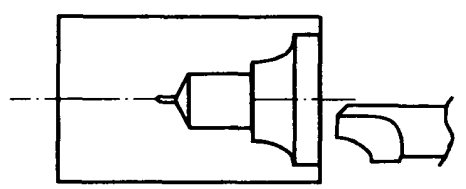

Fig.28 The 5th process -内径仕上げ加工 (2)鈴玉加工

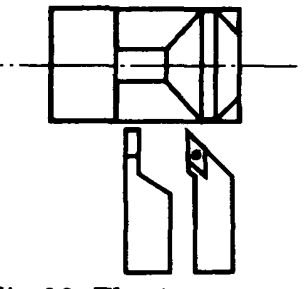

Fig.30 The 1st process - 外径仕上加工

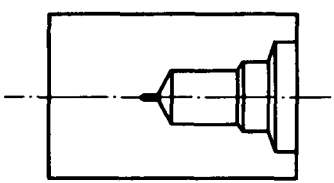

Fig.27 The 4th process -M3 下キリ穴加工

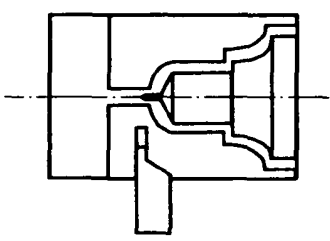

Fig.29 The 6th process ・外径仕上げ加工

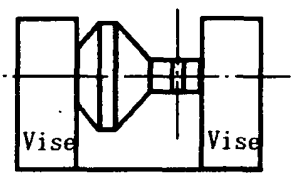

Fig.31 The 2nd process ・ 3 キリ穴あけ加工

（3鉿玉取り付け金具加工

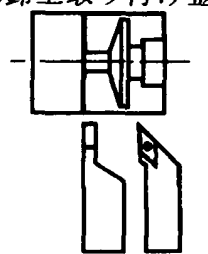

Fig.32 The lst proces

- 外径仕上加工

4）完成したB班の熊鈴をFig. 35 に示す.

5）感想 : 古賀敏夫君のレポートから

今回の熊鈴製作では，オリジナル製品を見て，それより よい性能，安価な製作を目標にしたため面白く，斬新な授 業であったと思う． 2 チーム編成での製作で競い合うこと ができ，また治具設計の勉強の後ということもあり，より 製作意欲が増し，よいものが作れたと思っている.

製作するに当り，熊鈴そのものを知ることが必要と考 え，インターネットなどによる情報収集を行ったうえで構 想を練った．他チームは，オーソドックスな鈴を作るとい うことだったので, デザイン，音色，性能のよさで負けな いようなものを考えた。 また，肉厚の決定，スカート分の 長さの決定など，音色などを予想しながら行っていった. 加工では, 鋳造以外の製作法が課せられたので, 切削加 工, 塑性加工の 2 種類の加工法を思いついた.

しかし，切削加工では材料費，製作費が，塑性加工では
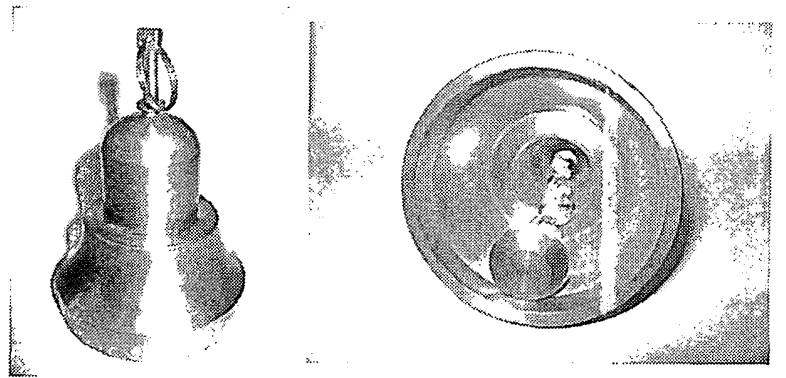

Fig.35 Bear bell manufactured by Team B
金型代が，それぞれ膨大となること，期限もあり，結局切 削加工に決定した．ただし，加工時間を短縮するために， 成形加工とした．熊鈴には, 当初, 鈴玉を 2 個つけて不規 則な音をと考えたが，サイズが小さくできなく残念であっ た.しかし音色はよく響き，満足した。

このように他チームと競い合いながら，チーム内で協力 し合い，物を製作するという経験はなかったので楽しかっ た. 加工法の決定や仕上がりの予想など，これまで知らな かったことが知れ勉強になった．設計から製作まで，材料 費，人件費，経費など考える貴重な授業であった。

今後は, チーム毎の製作費・性能の比較が行えたら良い と思う.チーム編成でのものづくり競技は，とても製作意 欲がわく.

\section{4. 站鈴つくり实践のまとめ}

物づくりに関して，最近，地元の中堅企業の社長から聞 いたことがある. 設計者(図面を描く役割) と技能者(物を 作る役割)両者の技術レベルのダウンについては，かなり 梁刻な問題である.いずれかが技術レベルを有していれ ば，何とか物づくりができていたが, , , ということのよう である. そのような意味からも, 工学教育の中で, 物づく りの事始的内容の授業があっても良いのではないかと考 え, 今回, 試行的に生産設計, 加工工程, 治具の考案など を要求した課題を実践してみた. 学生のレポートが示すよ うに,一忘の効果があったようだ.

なお， 2 班で製作された熊鈴について，今年度になって 行った打鈴による音の周波数解析の結果を Fig. 36 に示 す. 1 次， 2 次成分ともに，オリジナル熊鈴近傍を， $\mathrm{A}$ ， B雨班の熊鈴がはさんだ分布を示しており，オリジナルに ほぼ近い音色を生み出していることがわかった．学生諸君 もこの結果を知り，満足したようだ.

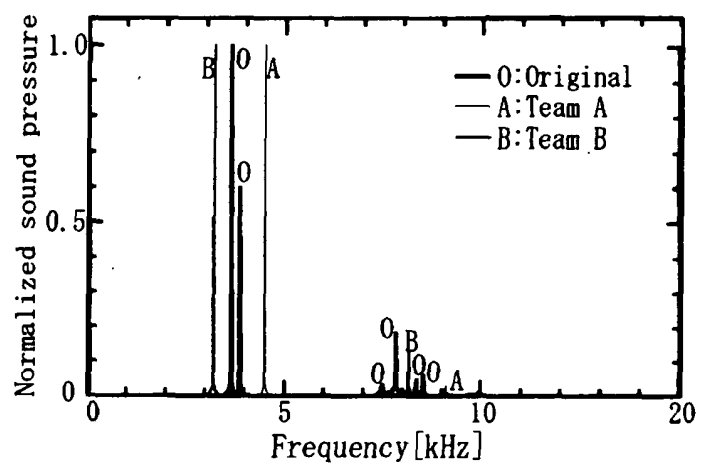

Fig.36 Frequency components of bear bells

\section{5. おわりに}

地味ではあるが，物づくりを支える基本技術，生産設 計, 加工工程, 各加工工程における効果的な治具の設計に 焦点を絞り，「熊鈴作り」を課題に，製品完成まで行った. 初めての試みであったため, 問題設定の厳密さ(生産量, ロット数など), 材料費, そして加工時間を含む詳細な費 用算出と評価など, 今後さらに行わなければならないこと も多い。

\section{考支献}

1）ヒューマンネットワーク高専, http : //www. hnk.jp/

2）川䗁, 木下: 先人の知恵を学び, 発展させる技術教育, 日本 機械学会, 技術と社会, 公開研究会, 講演会, (2001)

3）たとえば, 大西 : JISにもとづく機械設計製図便覧, 理工学 社 